\title{
ANALYSIS OF UKRAINIAN DIAGNOSTIC ARTICULATION TABLES
}

\author{
Oksana Pedchenko \\ Department of Acoustics and Acoustic Electronics \\ National Technical University of Ukraine «Igor Sikorsky Kyiv Polytechnic Institute» \\ 37 Peremohy ave., Kyiv, Ukraine, 03056 \\ ok.yashnik@gmail.com \\ Svitlana Lunova \\ Department of Acoustics and Acoustic Electronics \\ National Technical University of Ukraine «Igor Sikorsky Kyiv Polytechnic Institute» \\ 37 Peremohy ave., Kyiv, Ukraine, 03056 \\ svetlana_lunyova@yahoo.com
}

\begin{abstract}
The problem of creating Ukrainian diagnostic tables for the testing of hearing impaired people has not yet been resolved. The article dedicated to the linguistic material of existing articulation tables. The basic methodology of creating such tables is the recommendations for the compilation of Russian-language tables according to the rhythmic-dynamic indicators of the language. For comparison, corresponding tables in Russian have been analyzed. The performed analysis shows significant differences between the indicators of statistical analysis of Ukrainian-language tables. The atypical frequency of the use of separate letters for the Ukrainian language, as well as other phonological indicators, is revealed. Additionally, the articulation tables are not balanced. Their linguistic material, selected by column, is different in its indexes and cannot be interchangeable. That is why the use of spectral analysis of speech material during the compilation of articulation tables is proposed. This approach is objective to ensure the matching of the dictionary sample with the integral characteristics of the given language and allows to create balanced tables.

Due to the specifics of each language, it is necessary to create the appropriate language of their diagnostic tables, which should be used to test the state of hearing of the native speakers. This study will help to find out the feasibility of using existing Ukrainian language articulation tables and determine the ways to create an objective universal method for selecting a vocabulary that is typical of a given language.

Keywords: diagnostic articulation tables, speech intelligibility, speech audiometry, hearing loss.
\end{abstract}

\section{Introduction}

The deterioration in the performance of the auditory analyzer, which manifests itself in a lack of perception of a certain frequency range, has become one of the diseases that already concern more than ten percent of the world's population [1]. Every ninth inhabitant of Ukraine suffers hearing impairment $[1,2]$.

Age and other hearing loss are in the five non-critical diseases that cause significant harm to health and lead to disability. This statistic is based on measurement data known as the indicator of years lived with a disability [2]. It is determined that for the male part of the population, hearing impairment ranks third in the list of non-critical diseases for men.

In modern audiology, for the timely detection of the hearing pathology, methods of tonal and speech audiometry are used, which were created 17 years ago and were not subject to modernization until today [3].

Tonal audiometry is a subjective method of investigation that consists in checking the state of the auditory system with the help of tone signals of various frequencies generated by the audiometer, which are transmitted through a special air phone directly to the person's ear. With the help of threshold tonal audiometry, it is possible to determine the extent of hearing impairment and to classify the type of hearing loss, considering the level of lesion $[4,5]$.

Unlike tonal audiometry, with speech audiometry sound stimuli of complex shape with acoustic parameters are used, they change continuously. It is performed when adjusting the au- 
diometer in absolute scale to determine the thresholds of speech discrimination, comfortable and uncomfortable perception of speech, as well as auditory dynamic range $[5,6]$.

The audio material for speech audiometry is used in the form of diagnostic articulation tables pre-recorded and recorded on the phonogram. The most common of the Russian phonograms are: "Numbers test" [7] and "Test of real Russian words" [8], which are used in most listening centers of Ukraine for the Ukrainian and Russian-speaking population of the country, since there are no own approved tests on the territory of the country.

Each of the tests includes a number of tables. In the numbers test the table consists of 10 digits, and in the language test - of 20 words [8]. To determine the threshold of speech intelligibility for a given signal strength, the percentage of correctly repeated words to the total number of words in the table is calculated. Based on the research results, the hearing loss in speech perception is determined.

Since the study of hearing is carried out by both airborne and bone conduction, speech audiometry with a numerical test can serve as an objective test of the reliability of the patient's responses in threshold tonal audiometry [7].

\section{Literature review and problem statement}

Hearing with the help of language is an urgent issue today, as it serves as a way to rehabilitate communication in people with an impaired hearing system. To date, there are a large number of methods for measuring and assessing speech intelligibility, which makes it possible to divide them into two classes: subjective, which involve the use of speakers; and objective - articulation tests with experimental results $[9,10]$.

Diagnostic articulation tables for conducting speech audiometry should contain a significant amount of interchangeable linguistic material, since memorizing such tables leads to erroneous results in the studies. The selection of words should be typical for this language. It should show the peculiarity of linguistic creation, semantics and rhythm of the given language. So, the main issue in the development of articulation diagnostic tables should be the phonological composition of the language.

To emphasize the importance of these provisions, let's give an example of a complex way of developing articulation diagnostic tables in the Tajik language. The first attempt to develop such tables is presented in [11], which was subsequently criticized because of the lack of consideration for the specifics of linguistic creation and neglect of semantics. This argument led to the need to improve the tables taking into account the peculiarities of the Tajik language [11]. Let's note that for today a test material for Russian and number of European languages has already been created: English, German, Finnish, Swedish, French and Italian [12].

In Ukraine in 1984 in the laboratory of clinical audiology and vestibulology of the Kiev Research Institute of Otorhinolaryngology named after A. Kolomiychenko, the first tests for speech audiometry in the Ukrainian language were proposed $[13,14]$. The material for conducting speech audiometry consisted only of nouns, therefore could not fully display the semantic and grammatical features of the Ukrainian language.

In 2001, the so-called balanced word tables in Ukrainian were compiled in the same laboratory [15]. In some centers of auditory rehabilitation and hearing care in Ukraine, in particular, the Research Institute of Otorhinolaryngology named after A. Kolomiychenko, for speech audiometry and today use articulation Rymar tables.

The main criteria that are taken into account when choosing words for creating tables are the following $[1,14,16]$ :

- frequency of word usage in Ukrainian;

- word length in syllables; there are one-, two- and multi-complex;

- part of the speech to which the word belongs, namely: nouns, adjectives and a verb in the proportion of $3: 1$;

- presence of all phonemes in each group of the table;

- place of stress in the word;

- ratio of the vowels and consonants entering into each group of words and phonetic balance. 
In addition to tests for medical use, in 2009, Ukrainian-language articulation tables were also proposed for testing communication channels $[17,18]$.

At the heart of their creation lies the analysis of the frequency of letters of the Ukrainian alphabet. The authors processed about 580,000 characters of Ukrainian texts of different orientations. The verbal material of the created articulation tables is not limited in the number of syllables or letters, belongs to different parts of speech and is represented in arbitrary cases.

Analyzing the author's approach to the creation of the existing Ukrainian-language tables, it is concluded that it is quite subjective in the selection of typical words for a chosen language, and also mechanical, because the choice of language material is based on the statistical data of the language, namely, on calculating the average frequency of the use of letters .

In addition, to date there is no unified opinion on the part of the language that can and should be used in the compilation of linguistic material [19]. And also it is not defined, it is possible to use words in different cases, except nominative, in diagnostic tables.

Regarding the criteria for selecting material for diagnostic tables, in our opinion, the approach proposed in 2001 [15] is more complete and phonetically substantiated from the point of view of the typical character of words for the language. However, it remains unclear how these criteria are monitored.

Existing for today Ukrainian-language articulation tables are not completed with official confirmation of their legitimacy, which leads to widespread use of Russian-language tests.

As a result, the issue of creating diagnostic articulation tests in the Ukrainian language remains relevant today. There is still a need to develop an objective approach to the selection of language material for articulation tables and to verify their balance. Such approach should be the basis for the normative document for the creation of balanced Ukrainian-language diagnostic articulation tables.

The aim of research is a detailed analysis of the linguistic material of diagnostic articulation tables [15], such as those used in Ukraine for the diagnosis of hearing defects to date, which, in the future, will allow the development of a methodology for creating tables with the specificity of the Ukrainian language.

To achieve this aim, the following tasks are solved: analysis of diagnostic tables [15] on the correspondence between phonetic and average statistical indicators of the Ukrainian language, spectral estimation of the sound realization of the material that makes up the investigated tables.

\section{Materials and methods of research}

\section{1. Investigated materials}

Materials for research are presented by articulation tables (Table 1), which are used to diagnose the state of the auditory system on the territory of Ukraine.

Table 1

Articulation tables in Ukrainian of N. Rymar and A. Bagmut

\begin{tabular}{cccccccc}
\hline $\mathbf{1}$ group & $\mathbf{2}$ group & $\mathbf{3}$ group & $\mathbf{4}$ group & $\mathbf{5}$ group & $\mathbf{6}$ group & $\mathbf{7}$ group & $\mathbf{8}$ group \\
\hline $\mathbf{1}$ & $\mathbf{2}$ & $\mathbf{3}$ & $\mathbf{4}$ & $\mathbf{5}$ & $\mathbf{6}$ & $\mathbf{7}$ & $\mathbf{8}$ \\
\hline Рибалити & Бачити & Обов'язок & Бік & Кабіна & Бабуся & Березень & Барвистий \\
Давати & Будувати & Малювати & Вершник & Лікувати & Співати & Називати & Купувати \\
Герб & Грім & Гострий & Релігійний & Вигадувати & Вагон & Розгадувати & Змагатися \\
Ліс & Зелений & Галявина & Палити & Липень & Великий & Лівий & Лист \\
Масло & Комар & Зимовий & Морква & Мак & Мис & Мир & Каміння \\
Зупинити & Почервоніти & Монета & Назва & Нуль & Криниця & Намір & Розгніватися \\
Обережний & Рис & Корисний & Широкий & Розмір & Риба & Вирішувати & Доручення \\
Дзеркало & Народження & Кукурудза & Джерело & Родзинка & Переїжджати & Гудзик & Джем \\
Кінь & Кущ & Наказувати & Переконаний & Школа & Покірний & Кіт & Користь \\
\hline
\end{tabular}


Continuation of Table 1

\begin{tabular}{|c|c|c|c|c|c|c|c|}
\hline 1 & 2 & 3 & 4 & 5 & 6 & 7 & 8 \\
\hline Красуня & Насіння & Син & Сіль & Серпень & $\mathrm{CoH}$ & Січень & Сік \\
\hline Пустий & Питання & Вітати & Платити & Запитати & повертати & Дитина & Літак \\
\hline Парубок & Записувати & Піч & Парк & Виступати & Безпечний & Листопад & Шкарпетка \\
\hline Хата & Прохати & Хижий & Кохати & Хустка & Волохатий & Хибний & Охайний \\
\hline Ганчірка & Доручити & Чай & Відпочити & Причина & Розчісувати & Чистий & Почути \\
\hline Цукор & Оцінка & Цирк & Церква & Цінний & Цар & Цілий & Цифра \\
\hline Шахта & Шум & $\begin{array}{c}\text { Поширю- } \\
\text { вати }\end{array}$ & Кишеня & Машина & Дешевий & Горошинка & Вершина \\
\hline Рожевий & Бажати & Дружити & Жук & Дружина & Кожух & Жито & Жити \\
\hline Дощечка & Нащадок & Щука & Щавель & Щирий & Прощати & Щур & Щастя \\
\hline Район & Майор & Військо & Займати & Знайти & Руйнувати & Прийняти & Постійний \\
\hline Країна & Ялинка & Їсти & Буряк & Напоїти & Яма & Їдальня & Бур'ян \\
\hline Надійний & Дуб & Неділя & Одержати & Розповідати & Думка & Дата & Дійсний \\
\hline Зошит & Зоряний & Замок & Газон & Розумний & Сузір'я & 3ip & Золото \\
\hline Єдиний & Таємний & Взаємний & Маєток & Приємний & Єнот & Пацієнт & Єднати \\
\hline Шлюб & Лютий & Малюнок & Юнак & Людяний & Юрба & Калюжа & Юний \\
\hline Пиріг & Річка & Порада & Брат & Крок & Струм & Горіти & Винагорода \\
\hline Тин & Термін & Темп & Наступний & Мотор & Тема & Темний & Антена \\
\hline Місяць & Мудрий & Mope & Матір & Зима & Місто & Мокрий & Мити \\
\hline Фірмовий & Форма & Фокус & Телефонний & Фільм & Фермер & Фартух & Фікус \\
\hline Ризикувати & Швейний & Світлий & Перевірити & Двері & Овес & Двір & Звук \\
\hline Забезпечити & Півень & Пити & Повний & Пень & Спільний & Ліпити & Шпак \\
\hline
\end{tabular}

For comparison, the Ukrainian-language articulation tables [18] and also "Test of words of real Russian speech" [8] are used.

\section{2. The method of analysis of diagnostic articulation tables}

Methods for studying the existing Ukrainian-language articulation tables are based on the analysis:

- the frequency of the use of letters of the Ukrainian alphabet in the words from which the tables are composed;

- the number of syllables in individual words of the language material of the tables;

- places of stress in words;

- openness and closure of the end of words;

- the spectrum of groups of words from which the tables are composed.

\section{Results of studies of articulation diagnostic tables}

The statistical analysis of the percentage of the use of individual letters of the Ukrainian alphabet in relation to the total number of letters in the words of N. Rymar articulation tables is made for each column of the table separately. This is due to the fact that when analyzing articulation tables an important factor is their balance, that is, the opportunity to exchange language material in tables. Usually, when diagnosing the state of the auditory system, the entire articulation table is not read, but only its individual columns. Thus, the phonetic composition of the material of all the columns should have the same phonetic characteristics. The first column of the histogram of each letter refers to the first column of words. Accordingly, the second - to the second column of the table, etc. 
The results are presented as a percentage of the total number of letters in the words of each column of the table (Fig. 1, 2).

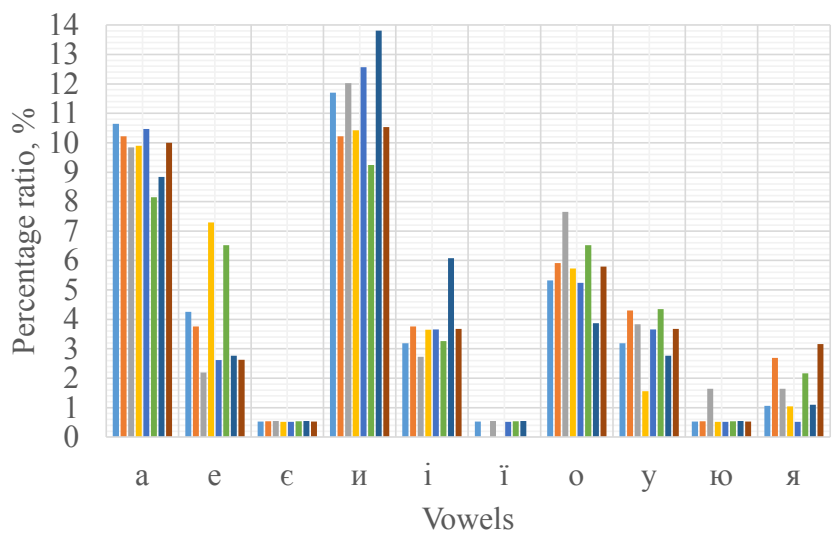

Fig. 1. Percentage ratio of the frequency of use of vowels in N. Rymar Ukrainian-language tables

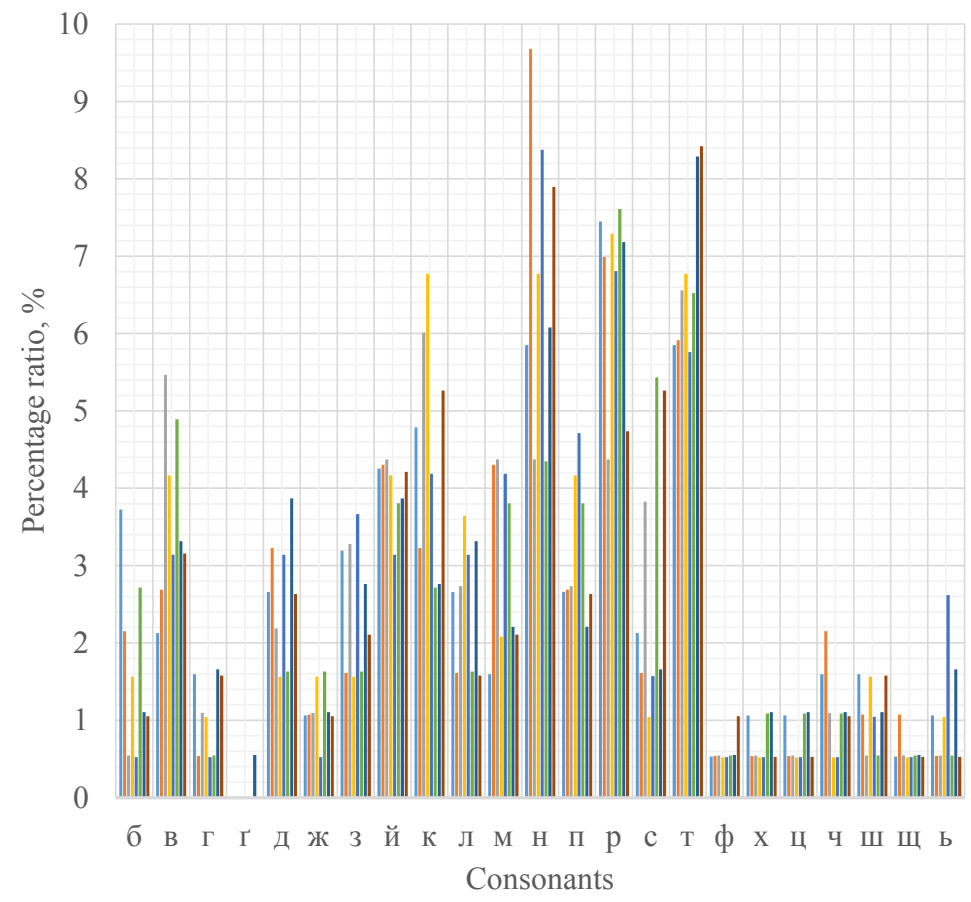

Fig. 2. Percentage ratio of the frequency of use of consonants in N. Rymar Ukrainian-language tables

Fig. 3 presents the results of a comparative statistical analysis of Ukrainian-language $[15,17]$ and Russian-language tables [8] for visual representation of a significant deviation in the frequency of the use of letters.

The first column of the histogram for each letter corresponds to N. Rymar table, the second to the O. Arkhypova tables and the third to Grinberg and Zinder tables.

In the Russian-language tables, the letters [e] and [ё], [ь] and [ъ] are identified.

Based on linguistic requirements, groups of words in the tables for speech audiometry should correspond to the rhythmic-dynamic structure of the language, which is closely related to the number of syllables and the place of stress in words.

The results of analysis of the number of syllables and the place of stress in words adopted in articulation tables [15] are presented in Tables $\mathbf{2 , 3}$. 


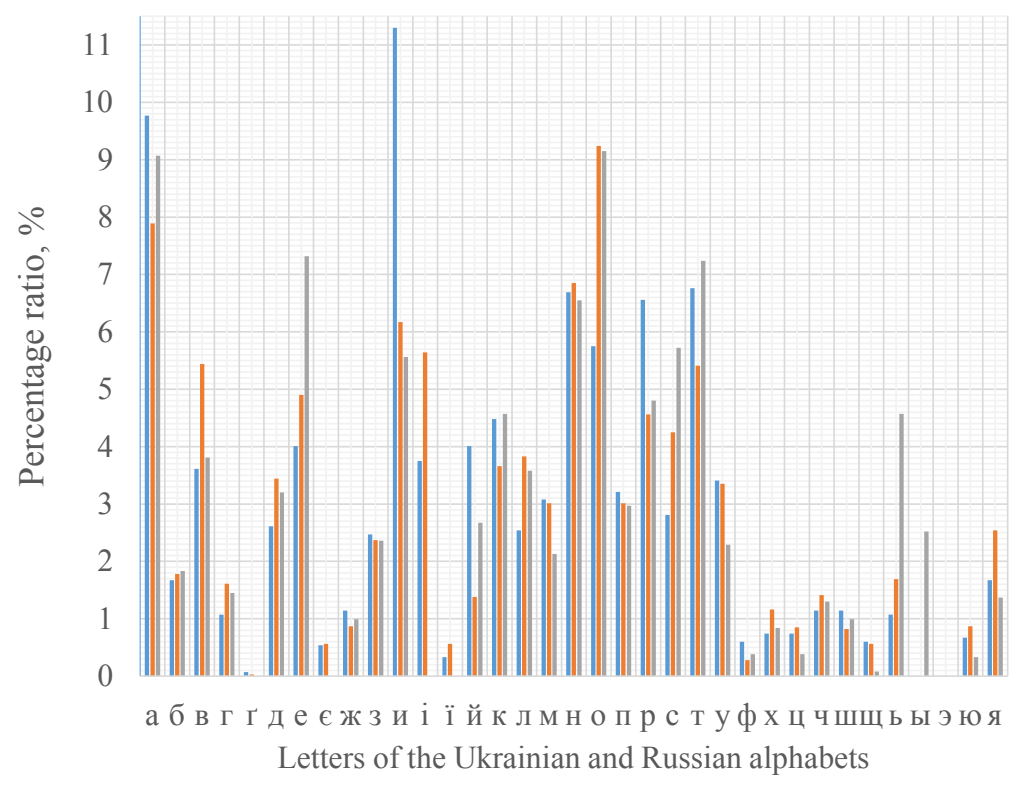

Fig. 3. Comparative histogram of the percentage of the use of letters in articulation tables $[8,15,17]$

Table 2

The percentage of syllables in words in articulation tables

\begin{tabular}{cc}
\hline Number of syllables & Percentage, $\%$ \\
\hline monosyllabic & 15,73 \\
disyllabic & 33,47 \\
trisyllabic & 33,87 \\
multisyllabic & 16,94
\end{tabular}

Table 3

Place of stress in words in articulation tables

\begin{tabular}{cc}
\hline Stress on the syllable & Percentage, $\mathbf{\%}$ \\
\hline 1 & 47,98 \\
2 & 40,73 \\
3 & 9,27 \\
4 & 2,02
\end{tabular}

An important condition for limiting the influence of the psychological factor of a person on the results of linguistic audiometry is the availability in words of diagnostic articulation tables of different structures inherent in a particular language.

The Ukrainian language is characterized by words that end in an open syllables $[14,15,19]$. The results of the corresponding study of the diagnostic tables are presented in a percentage in the Table 4.

Table 4

Percentage of open and closed syllables

\begin{tabular}{cc}
\hline Syllable structure & Articulation tables \\
\hline open syllable, $\%$ & 45,6 \\
closed syllable, $\%$ & 54,4
\end{tabular}


The authors of the paper suggest the use of the spectral method of analyzing linguistic material, which can serve as an objective assessment of the degree of balance of the tables.

For this, the following experiment was carried out. In the muffled chamber of the Acoustics and Acoustoelectronics Department of the National Technical University of Ukraine "Igor Sikorsky Kyiv Polytechnic Institute" with a background noise of 25 dBA, which corresponds to the permissible noise level for studio rooms, the existing Russian-language material of the articulation tables was recorded (Table 1) [15]. As a speaker, according to normative documents $[6,13,20]$, there was a person under the age of 35, without significant speech defects in communication. For recording, the condenser microphone ECM 8000 of the German company Behringer and the sound card Fast Track Pro of the American manufacturer M-Audio were used.

Since the hearing reacts to the averaged sound energy [10], the most convenient for objective analysis is the power spectrum, which does not contain information on the phase relationships of the frequency components.

The spectral power density of the speech signal $G(w)$ is the power released by the sound process in the frequency range $d f$. The total power $P$ in the frequency range $\left[f_{1}, f_{2}\right]$ is estimated as

$$
P=\int_{f_{1}}^{f_{2}} G(f) d f .
$$

Using the software package Matlab for each separate group of words (on the columns of Table 1) are plotted the spectral power density. For comparison, the obtained results are reflected in the general graph shown in Fig. 4, and their maximum difference is shown in Fig. 5.

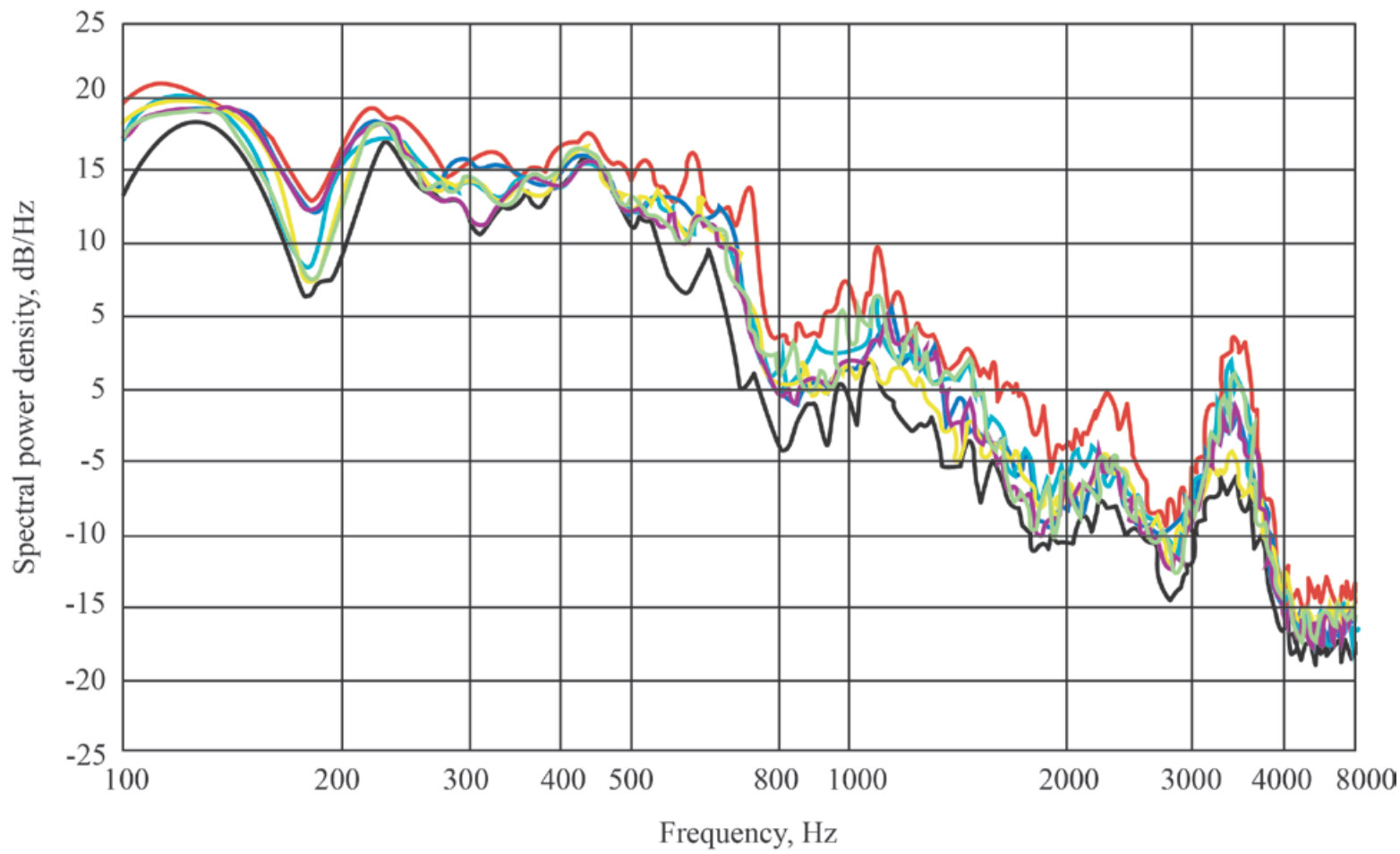

Fig. 4. The level of the spectral power density of the speech signal for individual columns of the Rymar articulation table

The obtained data of the difference in the power spectral density indicate the imbalance of the Ukrainian-language diagnostic articulation tables. 


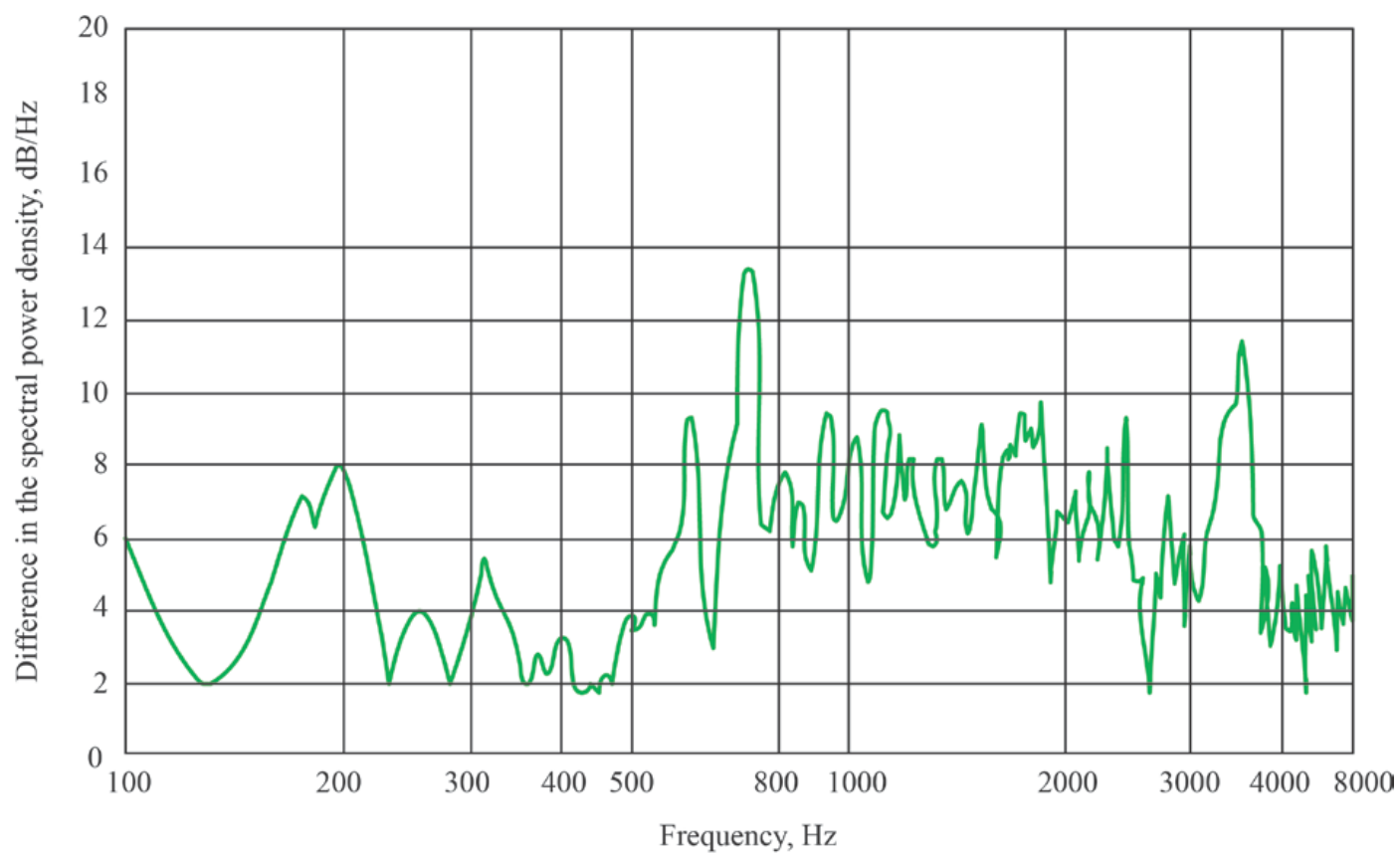

Fig. 5. The maximum difference in the spectral power density of the speech signal in individual columns of articulation tables

\section{Discussion of research results}

Analysis of histograms shown in Fig. 1, 2 indicate a significant uneven percentage of the use of both vowels and consonants in different columns of the articulation table. The vowels "e" and “и” (Fig. 1) and consonants «б», «Вв,, «К», «нН», «С» are used most unevenly (Fig. 2).

So, if evaluate the language material of the articulation table only by statistical characteristics, then the conclusion is that it is impossible to interchange the phonograms of different columns, that is, the tables are unbalanced.

In addition, the question arises, there are words (or a combination of sounds) from which a table is made, typical of the Ukrainian language.

Comparison of the first two columns for each letter of the histogram shown in Fig. 3 indicates a significant difference in the percentage use of a number of letters in the tables [15] and

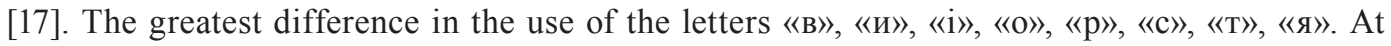

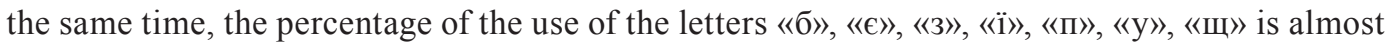
the same for both tables. Let's note that in the tables [15] and [17], the vowels «a», «и», «о» are most often repeated, while the specific vowels «ii» and «€» inherent in the Ukrainian language are used less.

The third column of the histogram (Fig. 3) illustrates the percentage of frequency of use of the corresponding letters in the Russian-language test, which is given for comparison. It is possible to see that for some letters the results coincide with the data for Ukrainian-language tests, and they differ for a number of letters.

These results can be explained both by differences in the phonetic characteristics of the Ukrainian and Russian languages, and by the incorrect sampling of words to the tables.

It is impossible to answer this question without an exhaustive objective evaluation of linguistic material, which can't be used as a percentage analysis of the use of individual letters. The confirmation of this thought is the fact that the hearing does not distinguish and differentiate each letter separately, but reacts to an audio message, that is, syllables. Therefore, a simple calculation of the frequency of letters does not indicate the typicality of the vocabulary for a given language.

Another criterion for selecting words for articulation tests is the correspondence of their sound realization to the rhythmic-dynamic structure of the language. 
The analysis of the number of syllables in words (Table 2), the location of the stressed syllable (Table 3), and the percentage ratio of the vocabulary endings (Table 4) is performed to test this condition, indicating that the specific features of the Ukrainian language are not up to the point. After all, checking the tables for the number of open and closed syllables at the end of the word (Table 4), through a small percentage of the use of closed syllables, indicates non-compliance with the condition, which reflects the specifics of the Ukrainian language.

This second criterion also can't be sufficient for the evaluation of linguistic material. In addition, according to statistical analysis of the frequency of letters and the number of syllables and the place of stress, it is very difficult to make articulation tables that will meet these requirements and at the same time be typical for a specific language.

Calculations performed by the proposed objective method of assessing linguistic material lead to the following results for the columns of Table 1 (Fig. 4). The level of the spectral power density of the speech signal for different columns of the articulation table differs from $2 \mathrm{~dB}$ to almost $14 \mathrm{~dB}$, depending on the frequency component (Fig. 5). The greatest deviations are observed in the frequency bands $600-800 \mathrm{~Hz}$ and $3-4 \mathrm{kHz}$, and also quite significant (up to $10 \mathrm{~dB}$, that is, 10 times the signal power) in the $800-2500 \mathrm{~Hz}$ and $200 \mathrm{~Hz}$ ranges.

These studies indicate not only a significant difference in the contribution of consonant sounds (high-frequency spectrum), but also vowel sounds (the formant frequencies of which lie in the low-frequency range).

Let's believe that such data testify to the imbalance of the articulation tables, is also confirmed by statistical analysis data (Table 3, 4).

The conclusion about the typicality of the words from which the table for the Ukrainian language was compiled can be made based on a comparison of the spectral characteristics of the speech material of the articulation table with the averaged spectrum of the Ukrainian language.

In the future, it is planned to create such objective data by spectral analysis of large volumes of Ukrainian-language sound information of various thematic purposes.

\section{Conclusions}

The criteria for selecting words for diagnostic Ukrainian-language tables, such as: statistical analysis of the frequency of the letters of the Ukrainian alphabet, the definition of the rhythmic-dynamic structure of the language by the number of syllables, the definition of the place of stress and the end of words can be useful for additional verification of the selected language material.

Even according to these criteria, the articulation tables [15] used in diagnostic hearing centers in Ukraine do not meet the requirements of a balanced table. Their conformity to the basic phonetic indicators of the Ukrainian language is questionable.

The proposed method of spectral evaluation of linguistic material makes it possible to perform an objective analysis of the vocabulary of articulation tables and is universal for the analysis of any language.

In the future, it can serve as a method for creating diagnostic tables that correspond to the basic phonetic characteristics of the Ukrainian language.

\section{References}

[1] Informatsionnyi sayt o problemakh slukha. Available at: http://uho.com.ua/ru/statistics

[2] Glukhota i poterya slukha (2017). Vsemirnaya organizatsiya zdravookhraneniya. Available at: http://www.who.int/mediacentre/factsheets/fs300/ru/

[3] Neiman, L. V., Boghomyliskyi, M. R.; Selyverstova, V. Y. (Ed.) (2001). Anatomiia fiziolohiia i patolohiia orhaniv slukhu ta movlennia. Moscow: Vlados, 224.

[4] Aldoshina, I. A. (2000). Osnovy psikhoakustiki: sbornik statey. 154.

[5] Tavartkiladze, G. A. (2013). Rukovodstvo po klinicheskoy audiologii. Moscow: Meditsina, 676 . 
[6] Voiers, W. D. (1977). Diagnostic Acceptability Measure for Speech Communication Syse tems. Proc. IEEE International Conference on Acoustics, Speech, and Signal Processing. Hartford, 204-207.

[7] Kharshak, Ye. M. (1964). Sbalansirovannyy chislovoy test dlya rechevoy audiometrii. Aktualnye voprosy kliniko- eksper. otolaringologii. Kyiv: Zdorov’ya, 140.

[8] Grinberg, G. I., Zinder, L. R. (1957). Tablitsy slov dlya rechevoy audiometrii v klinicheskoy praktike. Trudy Leningradskogo NII po boleznyam ukha, gorla, nosa i rechi, 10, 45-47.

[9] Vemyan, G. V. (1985). Peredacha rechi po setyam elektrosvyazi. Moscow: Radio i svyaz, 272.

[10] Didkovskiy, V. S., Didkovskaya, M. V., Prodeus, A. N. (2008). Akusticheskaya ekspertiza kanalov rechevoy kommunikatsii. Kyiv, 420.

[11] Rakhimova, M. M. (2006). Metody issledovaniya slukha rechyu na tadzhikskom yazyke. Doklady akademii nauk respubliki Tadzhikistan, 49 (10-12), 982-986.

[12] Mikhaylov, V. G. (2002). Diagnosticheskie artikulyatsionnye tablitsy. Akusticheskiy zhurnal, 48 (5), 705-712.

[13] Bazarov, V. G. (1984). Osnovy audiologii i slukhoprotezkhirovaniya. Moscow: Meditsina, 256.

[14] Bazarov, V. G., Bagmut, A. I. et. al. (1984). Rechevaya audiometriya na ukrainskom yazyke. Zhurnal ushnykh, nosovykh i gorlovykh bolezney, 5, 15-21.

[15] Rymar, N. V. (2002). Tablyci sliv dlia movnoi audiometrii ukrainskou movoiu. Zhurnal vushnykh, nosovykh i ghorlovykh khvorob, 3, 72-75.

[16] Pokrovskiy, N. B. (1962). Raschet i izmerenie razborchivosti rechi. Moscow: Svyazizdat, 392.

[17] Arkhypova, O. O., Zhuravliov, V. M. (2009). Chastotnyi analiz vykorystannia bukv ukrainskoi movy. Radioelektronika, informatyka, upravlinnia, 2, 53-56.

[18] Zhuravliov, V. M., Arkhypova, O. O., Dorovskykh, A. V. (2010). Tablytsi sliv ukrainskoi movy dlia artykuliatsiinykh vyprobuvan rozbirlyvosti informatsii, shcho peredaietsia traktamy zviazku. Zviazok, 1 (89), 9-11.

[19] Mishhanchuk, N. S., Radchenko, O. I., Karamzina, L. A. (2016). Movna audiometria dla klinichnoi audiologhii v suchasnykh umovakh. Zhurnal vushnykh, nosovykh i ghorlovykh khvorob, 2, 49-53.

[20] Altman, Ya. A., Tavartkiladze, G. A. (2003). Rukovodstvo po audiologii. Moscow: DMK Press, 360. 